\title{
MINERAL CHARACTERISTICS OF TROPICAL SALT LICKS IN SARAWAK, THE NORTHWEST OF BORNEO ISLAND
}

\author{
SIONG FONG SIM*1, JAYASILAN MOHD AZLAN ${ }^{2}$, NURUL ASNA HIDAYAH MIOR ABDUL \\ RAHMAN $^{2}$, SAMUEL LIHAN ${ }^{2}$ AND PEI LING KANG ${ }^{1}$
}

${ }^{1}$ Faculty of Resource Science \& Technology, ${ }^{2}$ Institute of Biodiversity and Environmental Conservation, Universiti Malaysia Sarawak, 94300 Kota Samarahan, Sarawak. Malaysia.

*Corresponding author: sfsim@unimas.my

Submitted final draft: 2 May $2020 \quad$ Accepted: 24 May 2020

http://doi.org/10.46754/jssm.2020.12.005

\begin{abstract}
Animals lick at the salt lick for mineral supplements. There is no scientific information available on the mineral compositions of salt licks in Sarawak. This paper reports the concentrations of $\mathrm{Na}, \mathrm{K}, \mathrm{Mg}$ and $\mathrm{Ca}$ in salt licks of Sarawak and their horizontal variability. Soil samples were collected from nine salt licks and at a distance of $100-500 \mathrm{~m}$ away. The samples were digested and analysed using an atomic absorption spectrophotometer. Samples from a non-salt lick site were also analysed, serving as the control. The concentrations of $\mathrm{Na}$ (nd $-136 \mathrm{mg} / \mathrm{kg}$ ), K (454-1834 mg/kg), Ca (nd $1017 \mathrm{mg} / \mathrm{kg})$ and $\mathrm{Mg}(450-3627 \mathrm{mg} / \mathrm{kg})$ in the nine-salt licks varied considerably. The sites observed with sodium craving species (leeches and butterflies) were confirmed with profound $\mathrm{Na}(90-117 \mathrm{mg} / \mathrm{kg})$, higher than that in the control $(45.65 \mathrm{mg} / \mathrm{kg})$. The mineral concentrations in the salt licks were reduced as the horizontal distance increased. At 500 $\mathrm{m}$, the mineral concentrations in most salt licks were found below the control. The findings in this study can be used to recommend a suitable buffer distance for wildlife conservation and sustainable management of the salt lick deposits in this region.
\end{abstract}

Keywords: Sustainable management, horizontal variability, sodium-craving behaviour. Abbreviations: $\mathrm{Na}, \mathrm{K}, \mathrm{Ca}, \mathrm{Mg}, \mathrm{PCA}$

\section{Introduction}

Salt licks are places rich in essential minerals where animals regularly visit to lick the soil/ water to supplement their diet. Animal footprints have been consistently captured at these natural deposits substantiating their importance to the animals. At salt licks in Deramakot Forest Reserve, Sabah, footage of 40 species was found with mammalians being the most dominant group of animals observed. Some endangered species such as Asian elephant and Orangutan were also spotted (Matsubayashi \& Lagan, 2014). The species diversity and frequency of animal visitation usually depend on the habitat nature, dietary needs, seasonal movements and reproductive activity of the animals. Lactating female mountain goats visit salt licks for Na supplement because their diet of alpine vegetation is low in $\mathrm{Na}$; the salt licks also provide $\mathrm{Mg}$ to offset their high dietary $\mathrm{K}$ intake (Poole et al., 2010). On the other hand, some wild herbivores lick from the deposits for detoxification of elements that are widespread in their habitats or taken up through ingestion (Panichev et al, 2017).

Salt licks are commonly characterised with elevated sodium $(\mathrm{Na})$, potassium $(\mathrm{K})$, calcium $(\mathrm{Ca})$, magnesium $(\mathrm{Mg})$ and possibly other elements such as nitrogen $(\mathrm{N})$, phosphorus $(\mathrm{P})$, iron $(\mathrm{Fe})$, copper $(\mathrm{Cu})$, zinc $(\mathrm{Zn})$ and chloride $\left(\mathrm{Cl}^{-}\right)$(Holdo et al., 2002; Brightsmith \& Aramburu, 2004; Matsubayashi et al., 2007; Mills \& Milewski, 2007; Powell et al., 2009). As reported by Ramachandran et al (1995), the mineral contents in salt licks can be 3 - 4 times higher than that found at the control site. The abundance of minerals may vary considerably, even in salt licks from similar geographical background; for example, the concentration of $\mathrm{Na}$ in five salt licks of the Amazon Basin could range from as low as $29 \mathrm{mg} / \mathrm{kg}$ to $1361 \mathrm{mg} / \mathrm{kg}$ (Molina et al., 2014). 
On one hand, salt licks play a vital role in providing animals with minerals required to maintain their health. On the other hand, salt licks serve as an important resource for the locals; sambar deer, Bornean yellow muntjac, mousedeer and bearded pig are commonly hunted at the salt licks for local consumption (Hon \& Shibata, 2013). Uncontrolled hunting activities could pose the risk of wildlife exploitation tipping the ecological balance. For this reason, buffer protection zones have been regulated, in Sabah, hunting is illegal within 500 m of a salt lick. Wildlife Conservation Act 2010 was further gazetted where hunting is prohibited within $400 \mathrm{~m}$ of a salt lick. This enforcement, however, is yet to be stipulated in the Ordinance of Sarawak, leaving the salt licks vulnerable to abuse.

Salt licks in Sarawak are identified by the locals based on animal footage. In recent years, camera trapping technique is gaining increasing popularity for species inventories and population density estimation in protected areas (Maiwald \& Jayasilan, 2018). Hon et al (2020) recorded footage of 19 species at salt licks in logging concessions of central Sarawak where endangered Borneo bay cat was also captured on camera at the reclaimed forest. Research efforts to establish species diversity and ecological dynamics at salt licks in Sarawak continue to gain attention. The findings serve as baseline data to facilitate formulation of an effective policy for sustainable management of these natural deposits. It is also important to determine the chemical characteristics of the salt licks where this information complements the observation and ecological data to provide a better insight on the diversity and utilisation of salt licks by wildlife. To the best of our knowledge, the chemical compositions and distributions of minerals in salt licks of Sarawak are yet to be explored.

Hence, the objectives of this study are: 1) to determine the mineral compositions in nine salt licks of Sarawak; 2) to compare the mineral compositions between salt licks and 3) to evaluate horizontal variability of minerals in the salt licks. The animal footage suggests that the local salt licks, like other salt licks elsewhere, are fortified with essential minerals required by animals for supplement.

\section{Materials and Methods}

\section{Sampling}

A total of nine salt licks in the vicinity of Loagan Bunut, Long Selaan, Lio Mato and Kapit in Sarawak was studied (Figure 1). The GPS coordinates and site descriptions are summarised in Table 1 (the coordinates will not be revealed in full to protect the licks from hunters). Characteristically, most salt licks are found near rivers with a bare zone of vegetation, except the inactive lick in Loagan Bunut. Figure 2 shows a photo of the salt lick of Sungan Semait Hulu. Generally, the sites were chosen based on their accessibility and potential disturbances in adjacent areas.

In this study, soil samples were collected from three random locations at the salt licks and at a distance of $100 \mathrm{~m}, 200 \mathrm{~m}, 300 \mathrm{~m}, 400 \mathrm{~m}$ and $500 \mathrm{~m}$ away. The samples were stored in plastic bags and kept in a cooler box for transportation to the laboratory. At the laboratory, the samples were stored at $-20{ }^{\circ} \mathrm{C}$ until further analysis to prevent degradation. A soil sample from a confirmed non-salt lick source (in Kuching, the capital city of Sarawak) was also collected to serve as the control for comparison. 


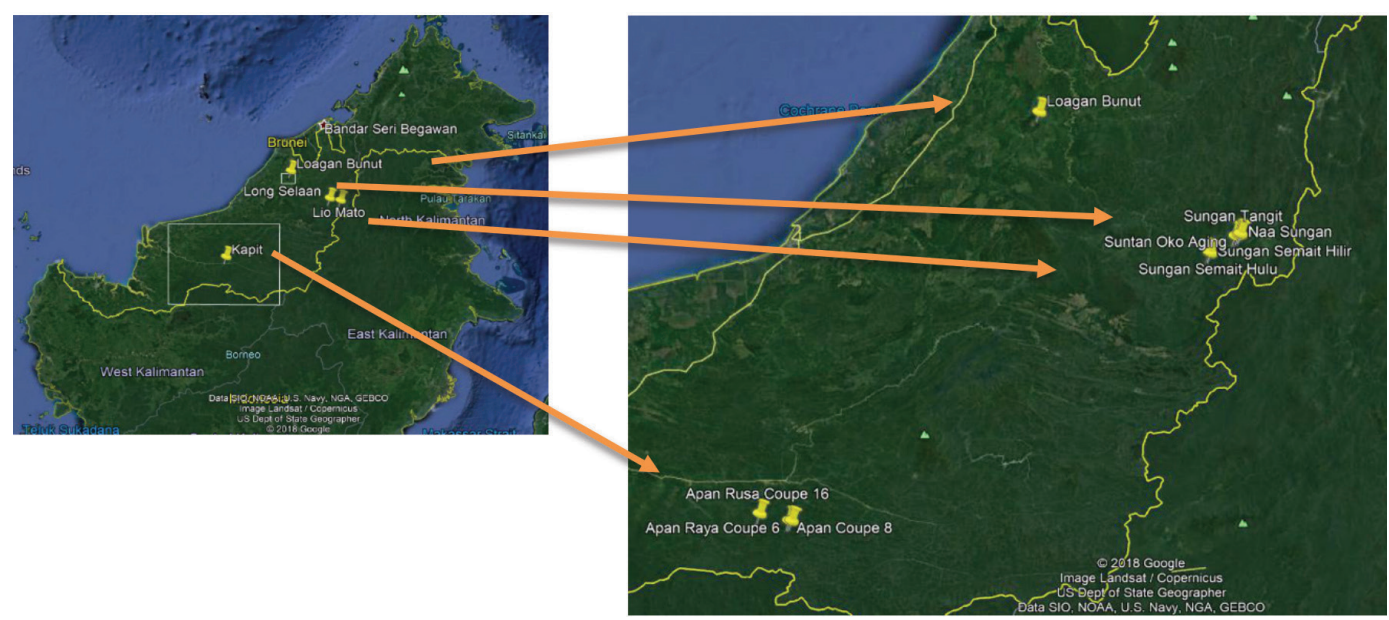

Figure 1: Locations of the nine salt licks distributed from central to the interior parts of Sarawak

Table 1: Site descriptions and GPS coordinates of the nine mineral licks.

\begin{tabular}{|c|c|c|}
\hline Salt licks & $\begin{array}{c}\text { GPS } \\
\text { coordinates }\end{array}$ & Site description \\
\hline $\begin{array}{l}\text { Loagan Bunut (LB) } \\
(\mathrm{n}=18)\end{array}$ & $\begin{array}{c}3^{\circ} 46^{\prime} \mathrm{N} \\
114^{\circ} 15^{\prime} \mathrm{E}\end{array}$ & $\begin{array}{l}\text { Located right behind the Loagan Bunut hostel facilities and are } \\
\text { considered an inactive salt lick by locals as no animal footprints } \\
\text { were discovered. The salt lick is covered with vegetation and the soil } \\
\text { is yellowish brown in colour, moist and soft. }\end{array}$ \\
\hline $\begin{array}{l}\text { Sungan Semait Hilir, } \\
\text { Long Selaan }\left(\mathrm{SS}_{\text {Hilir }}\right) \\
(\mathrm{n}=9)\end{array}$ & $\begin{array}{l}3^{\circ} 4^{\prime} \mathrm{N} 115^{\circ} \\
\quad 5^{\prime} \mathrm{E}\end{array}$ & $\begin{array}{l}\text { This salt lick is rocky and the canopy is relatively denser than the } \\
\text { adjacent salt lick of Sungan Semait Hulu. The soil is moist and } \\
\text { brown in colour. }\end{array}$ \\
\hline $\begin{array}{l}\text { Sungan Semait Hulu, } \\
\text { Long Selaan }\left(\mathrm{SS}_{\text {Hulu }}\right) \\
(\mathrm{n}=18)\end{array}$ & $\begin{array}{l}3^{\circ} 4^{\prime} \mathrm{N} 115^{\circ} \\
\quad 5^{\prime} \mathrm{E}\end{array}$ & $\begin{array}{l}\text { Located not far from Sungan Semait Hulu, the area is found on a } \\
\text { rocky slope. Colonies of leeches were found and it is one of the most } \\
\text { popular salt licks for hunting. There is no vegetation within the salt } \\
\text { lick and the soil is black in colour. }\end{array}$ \\
\hline $\begin{array}{l}\text { Naa Sungan, Lio } \\
\text { Mato (NS) }(\mathrm{n}=18)\end{array}$ & $\begin{array}{l}3^{\circ} 10^{\prime} \mathrm{N} \\
115^{\circ} 14^{\prime} \mathrm{E}\end{array}$ & $\begin{array}{l}\text { Located not far from the river bank, the soil is wet and black in } \\
\text { colour. The canopy is quite dense, with numerous animal footprints } \\
\text { found nearby. }\end{array}$ \\
\hline $\begin{array}{l}\text { Suntan Oko Aging, } \\
\text { Lio Mato (SOA) } \\
(\mathrm{n}=18)\end{array}$ & $\begin{array}{l}3^{\circ} 10^{\prime} \mathrm{N} \\
115^{\circ} 14^{\prime} \mathrm{E}\end{array}$ & $\begin{array}{l}\text { The soil is wet and black in colour. The canopy gap cannot be } \\
\text { determined as the salt lick is covered in fallen trees. Flocks of } \\
\text { butterflies are observed. }\end{array}$ \\
\hline $\begin{array}{l}\text { Suntan Tangit, } \\
\text { Lio Mato (ST) } \\
(\mathrm{n}=18)\end{array}$ & $\begin{array}{c}3^{\circ} 9^{\prime} \mathrm{N} \\
115^{\circ} 13^{\prime} \mathrm{E}\end{array}$ & $\begin{array}{l}\text { The area is constantly submerged in water. The canopy is quite dense } \\
\text { with no vegetation in the salt lick. The soil is black in colour. }\end{array}$ \\
\hline $\begin{array}{l}\text { Apan Rusa Coupe } \\
\text { C6, Kapit (S6) }(\mathrm{n}=18)\end{array}$ & $\begin{array}{l}1^{\circ} 47^{\prime} \mathrm{N} 112^{\circ} \\
52^{\prime} \mathrm{E}\end{array}$ & $\begin{array}{l}\text { It is located next to the riverbank with muddy soil in yellowish brown } \\
\text { colour. Plentiful animal footprints were seen but with no vegetation. }\end{array}$ \\
\hline $\begin{array}{l}\text { Apan Coupe } 8 \text {, Kapit } \\
\text { (S8) }(\mathrm{n}=18)\end{array}$ & $\begin{array}{l}1^{\circ} 45^{\prime} \mathrm{N} 113^{\circ} \\
1^{\prime} \mathrm{E}\end{array}$ & $\begin{array}{l}\text { Located next to the riverbank with soil in yellowish brown colour } \\
\text { but there is no vegetation in the salt lick. }\end{array}$ \\
\hline $\begin{array}{l}\text { Apan Raya Coupe 6, } \\
\text { Kapit (AR) }(n=18)\end{array}$ & $\begin{array}{l}1^{\circ} 45^{\prime} \mathrm{N} 113^{\circ} \\
2^{\prime} \mathrm{E}\end{array}$ & $\begin{array}{l}\text { Located in the middle of the river with no vegetation but flocks of } \\
\text { butterflies are found and the salt lick is expected to submerge during } \\
\text { high water level. }\end{array}$ \\
\hline
\end{tabular}




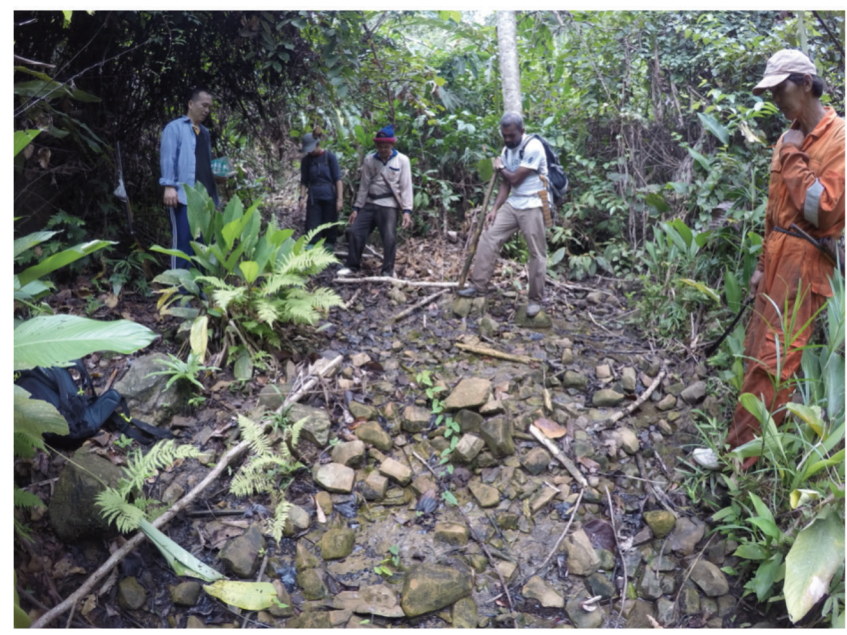

Figure 2: A photo of the salt lick of Sungan Semait Hulu

\section{Acid Digestion and Metal Analysis}

At the laboratory, soil samples were air dried, ground into powder and sieved through a $2 \mathrm{~mm}$ sieve to remove unwanted particles. A $0.5 \mathrm{~g}$ of soil sample was weighed and added with $\mathrm{HCl}$ and $\mathrm{HNO}_{3}$ in a ratio of $3: 1(\mathrm{v} / \mathrm{v})$. The sample was digested for five hours using the digestion block system (Durablock, AGS Scientific). When the digestion process was completed, the sample was left to cool to room temperature, filtered through a $0.45 \mu \mathrm{m}$ membrane filter and diluted to 100 $\mathrm{mL}$ with deionised water (Uddin et al., 2016). The sample was analysed for $\mathrm{Ca}, \mathrm{K}, \mathrm{Mg}$ and $\mathrm{Na}$ using an Atomic Absorption Spectrophotometer (Thermo Scientific iCE 3000). A calibration curve was constructed based on three standards. A sample detected with concentration outside the calibration range was diluted and sample blank was similarly analysed to monitor potential contamination. The samples were analysed in triplicates with the concentration reported in $\mathrm{mg} / \mathrm{kg}$ (dry weight) according to the following equation. A total of 156 samples were analysed including the control (for $\mathrm{SS}_{\mathrm{Hili}}$, samples were collected up to $200 \mathrm{~m}$ ).

\section{Statistical Analyses}

Principal Component Analysis (PCA) was used to examine the underlying clustering pattern of the data. Prior to PCA, the data was square rooted and standardised to ensure all variables are comparable. Analysis of Variance (ANOVA) was employed to compare the mean concentrations of elements at $95 \%$ confidence interval, with Tukey's test applied for multiple comparisons. Pearson's correlation was used to calculate the inter-relationships between minerals. All statistical analyses were performed using Matlab R2013a.

\section{Results and Discussion}

The concentrations of $\mathrm{Na}, \mathrm{K}, \mathrm{Ca}$ and $\mathrm{Mg}$ from nine salt licks were subjected to PCA for exploratory analysis to determine whether samples from different sites are distinguishable. The first two principal components (PC) explain $75.11 \%$ of the total variance with the biplot in Figure 3 demonstrating two observable clusters. Samples from Sungan Tangit (ST), Sungan Semait Hilir $\left(\mathrm{SS}_{\mathrm{Hili}}\right)$ and Loagan Bunut (LB) were in one cluster with positive PC1,

Concentration $\left(\frac{\mathrm{mg}}{\mathrm{kg}}\right)=\frac{\left(\text { conc.in } \frac{\mathrm{mg}}{\mathrm{L}}\right)(\text { final volume of dilution, } \mathrm{L})}{\text { sample weight }(\mathrm{kg})}$ 


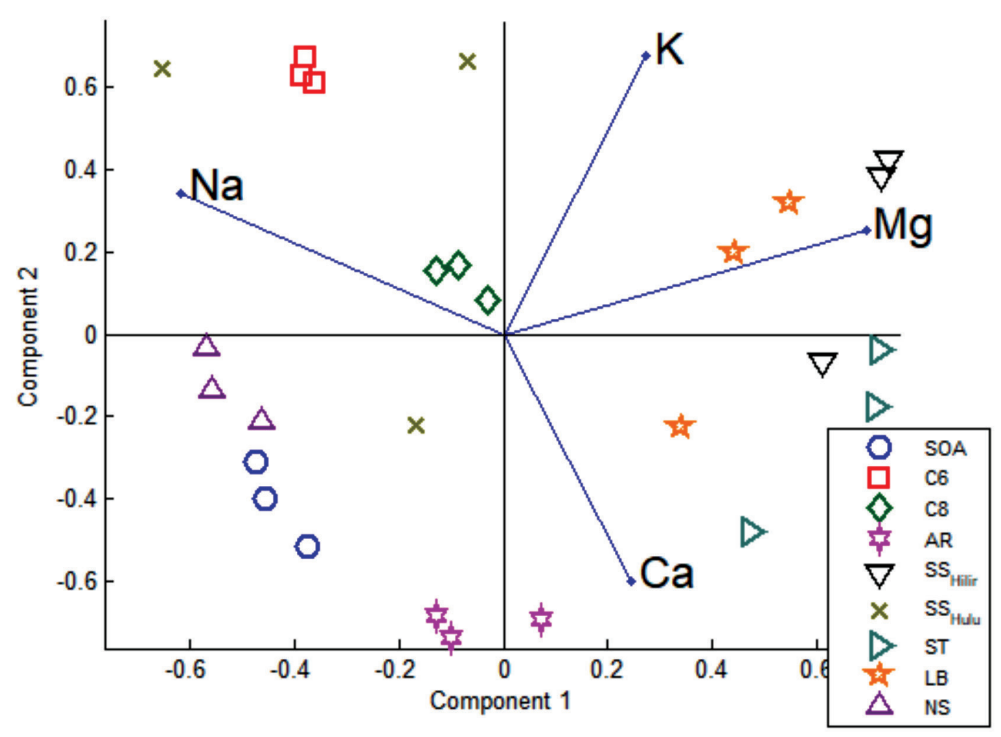

Figure 3: PCA biplot of mineral contents in the nine salt licks

and the remaining exhibited negative score values. The biplot infers negative correlations between $\mathrm{Na}$ and other elements, with the three aforementioned sites characterised with lower $\mathrm{Na}$ abundance.

Figure 4 shows the average mineral concentrations in the nine salt licks and the control. As postulated based on PCA biplot, $\mathrm{Na}$ detected in ST, $\mathrm{SS}_{\mathrm{Hilir}}$ and LB are markedly less profound (nd $-11 \mathrm{mg} / \mathrm{kg}$ ), lower than the concentration present at the control site (45.65 $\mathrm{mg} / \mathrm{kg}$ ). In a similar manner, Klaus et al., (1998) compares $\mathrm{Na}$ in the salt lick and forest top soil (control site), revealing lower concentration in the former. The unexpectedly low $\mathrm{Na}$ abundance in salt licks is possibly related to the antagonistic interactions between elements, for example, high $\mathrm{Ca}$ in soil tends to cause $\mathrm{Na}$ displacement promoting leaching of (Carrow $\&$ Duncan, 2011). Conversely, Sungan Semait Hulu $\left(\mathrm{SS}_{\mathrm{Hulu}}\right)$, Suntan Oko Aging (SOA) and Apan Rusa Coupe 6 (C6) $(90-117 \mathrm{mg} / \mathrm{kg})$ are distinguished with prevailing $\mathrm{Na}$ where some interesting observations were recorded onsite. At SOA and C6, flocks of butterflies were spotted whilst at $\mathrm{SS}_{\mathrm{Hulu}}$, large colonies of leeches were found (Figure 5). The elevated $\mathrm{Na}$ level confirms the sodium craving behaviour of both species. Leeches live in freshwater habitat that is hypoosmotic to their body fluid susceptible to loss of Na. They live in Na-rich salt licks for active uptake of $\mathrm{Na}$ into their body (Weber et al., 1993; Milde et al., 2001). Butterflies, on the other hand, have been well known for their puddling behaviour (sipping from salt licks). Physiologically, female butterflies tend to lose $\mathrm{Na}$ during the egg-laying process where they often replenish $\mathrm{Na}$ from their partner during mating. For this reason, male butterflies use salt licks to supplement $\mathrm{Na}$ for their sperm (Hadley, 2017). Besides leeches and butterflies, moths and bees are two other sodium seeking insects reported (Bogggs \& Lee, 2008). According to Moe (1993), Na is the mineral most sought after by animals in the tropical region. It is also noteworthy to discuss the mineral characteristics in LB, a salt lick that is labelled 'inactive' as animal footage is no longer observed. As illustrated, the mineral contents in $\mathrm{LB}$, particularly $\mathrm{K}$ and $\mathrm{Mg}$, are higher than that in the control suggesting that the site may still serve as a source for minerals. The cessation of animal visitation may be potentially associated with human disturbance in adjacent areas.

The intermetallic relationships of $\mathrm{Na}, \mathrm{K}$, $\mathrm{Mg}$ and $\mathrm{Ca}$ in the nine salt licks were evaluated. 

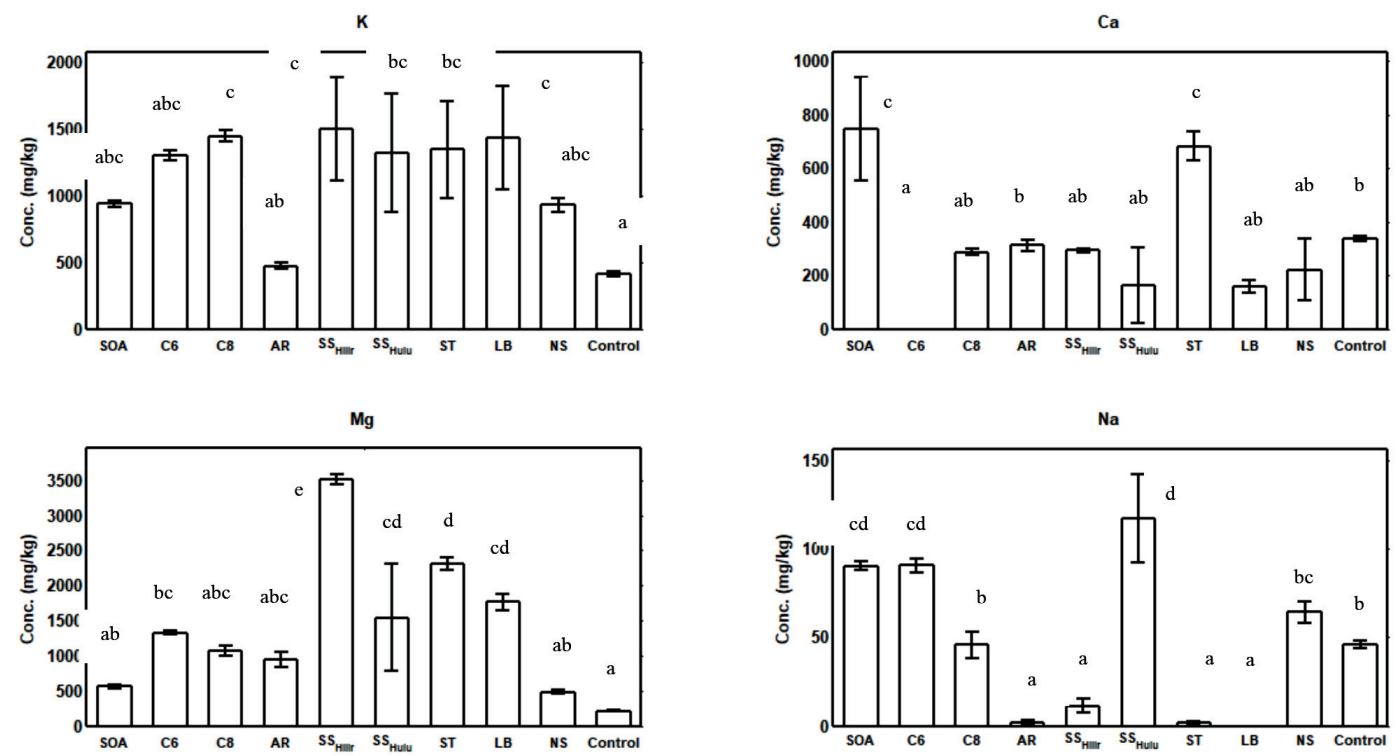

Figure 4: The mineral contents in nine salt licks of Sarawak (different letters indicate significant difference at $p<0.05)$

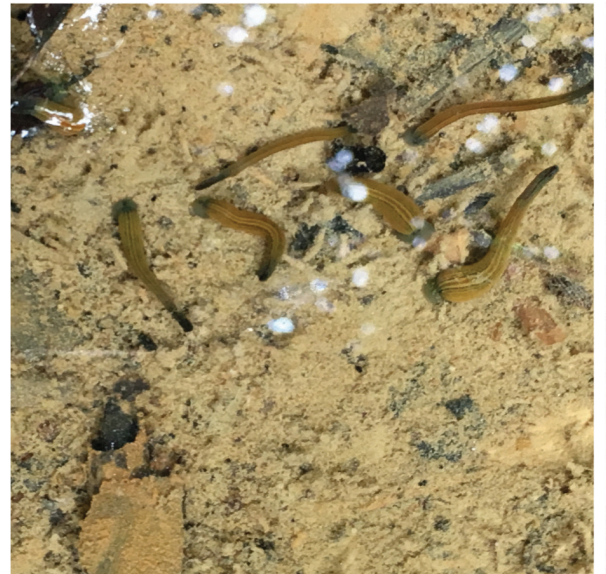

(a)

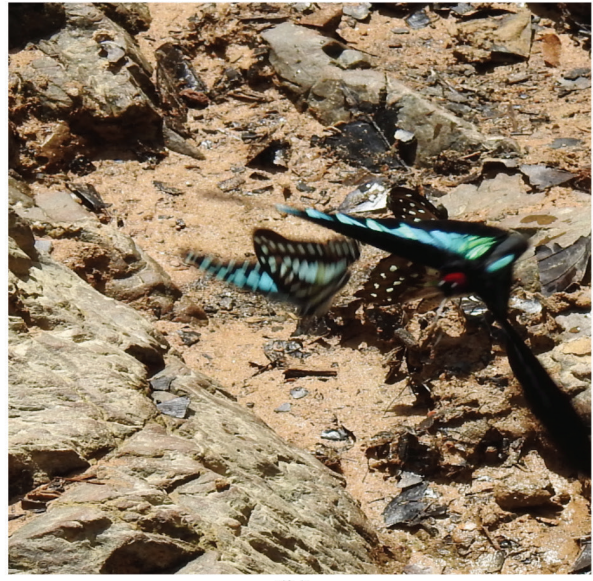

(b)

Figure 5: (a) Colonies of leeches and (b) flocks of butterflies observed at the salt licks of $\mathrm{SS}_{\mathrm{Hulu}}$ and C6

A strong positive correlation was elucidated between $\mathrm{Ca}-\mathrm{Mg}, \mathrm{K}-\mathrm{Mg}, \mathrm{Na}-\mathrm{K}$ in at least four salt licks studied. $\mathrm{Mg}$ and $\mathrm{Ca}$ are essential for the formation of bones whilst $\mathrm{Na}$ and $\mathrm{K}$ both play an important role in osmoregulation (Lameed \& Adetola, 2012). The significant direct relationships between $\mathrm{Ca}-\mathrm{Mg}$ and $\mathrm{K}-\mathrm{Mg}$ are similarly reported by Neilsent \& Edwards (1982).
There is an appreciable variation in mineral compositions from the nine salt licks. At SOA, where $\mathrm{Na}$ is abundant the salt lick is also enriched with $\mathrm{Ca}$. ST and $\mathrm{SS}_{\mathrm{Hilir}}$, on the other hand, share Na-depriving environment and they are characterised with high $\mathrm{Ca}$ and $\mathrm{Mg}$, respectively. Table 2 compares the mineral concentrations reported in the previous studies with the present study. The mineral concentration in salt licks from various geographical locations 
Table 2: Comparisons of mineral contents in salt licks reported in previous studies with the present study

\begin{tabular}{|c|c|c|c|c|}
\hline \multirow[t]{2}{*}{ Salt licks } & \multicolumn{4}{|c|}{ Concentration (mg/kg) } \\
\hline & $\mathbf{N a}$ & $\mathbf{K}$ & $\mathbf{C a}$ & Mg \\
\hline Amazon Basin ${ }^{\mathrm{a}}$ & $29-1361$ & $101-3823$ & $92-4240$ & $93-978$ \\
\hline $\begin{array}{l}\text { Tharaka-Nithi County, } \\
\text { Kenya }^{\text {b }}\end{array}$ & nd -11279 & $267-1800$ & $1125-44445$ & $2117-14063$ \\
\hline Southwestern Nepal ${ }^{\mathrm{c}}$ & 1198 & 132 & 2395 & 731 \\
\hline $\begin{array}{l}\text { Chinnar Wildlife Sanctuary, } \\
\text { India }^{d}\end{array}$ & $1380-1526$ & $875-924$ & $630-690$ & $520-570$ \\
\hline $\begin{array}{l}\text { Sundown National Park, } \\
\text { Australia }^{\mathrm{e}}\end{array}$ & $415-983$ & $136-141$ & $443-1561$ & $539-886$ \\
\hline $\begin{array}{l}\text { Loskop Dam Nature } \\
\text { Reserve, South Africa }\end{array}$ & $561-5795$ & $714-2818$ & $1017-9501$ & $714-2818$ \\
\hline $\begin{array}{l}\text { Deramakot Forest Reserve, } \\
\text { Sabah }^{\mathrm{g}}\end{array}$ & $200-600$ & $1300-10060$ & $700-4400$ & $1200-8600$ \\
\hline This study & nd -136 & $454-1834$ & nd - 1017 & $450-3627$ \\
\hline
\end{tabular}

nd not detected

${ }^{a}$ Molina et al (2014)

${ }^{\mathrm{b}}$ Nderi et al (2015)

${ }^{\mathrm{c}}$ Moe (1993)

${ }^{d}$ Ramachandran et al (1995)

${ }^{\mathrm{e}}$ Best et al (1993)

${ }^{\mathrm{f}}$ Stephenson et al (2011)

g Matsubayashi \& Lagan (2014)

greatly and unpredictably. The local salt licks demonstrate relatively lower $\mathrm{Na}$ with narrower range, comparable to the tropical salt licks of the Amazon Basin (Molina et al., 2014) and the Deramakot Forest Reserve (Matsubayashi \& Lagan, 2014). Macronutrient deficiency is typical to tropical soil as a result of intensive weathering and leaching under humid tropics climate (Jordan, 1985; Vitousek \& Sanford, 1986).

As mentioned earlier, no regulation has been imposed in Sarawak pertaining to the hunting practice around salt lick area. The World Wildlife Fund for Nature Malaysia (WWF-Malaysia) has urged the authorities to set the buffer zone for salt licks (Kamini, 2014). The organisation recommends a minimum of 2 $\mathrm{km}$ based on scientific ecological study using camera trapping technique. If the horizontal mineral profile can be established, the radius substrates can be determined. The spatial distribution and abundance of minerals can be used to recommend a suitable buffer distance at the salt licks. Figure 6 shows the average mineral concentrations in the salt licks and at an increasing distance away from the salt licks, up to $500 \mathrm{~m}$, with the dashed lines indicating concentrations in the control. Hypothetically, a declining concentration is anticipated as the horizontal distance increases and this is reasonably well corroborated. At a distance of $500 \mathrm{~m}$, the mineral concentrations are close to or well below the background level for most salt licks except $\mathrm{SS}_{\text {Hulu }}$ where the concentrations of $\mathrm{Mg}$ and $\mathrm{K}$ remain above the control. Based on the horizontal variability of minerals in the nine salt licks, it is believed that the buffer distance of $500 \mathrm{~m}$ stipulated by the Wildlife Conservation Enactment in Sabah is reasonable to ensure protection and conservation of wildlife. 

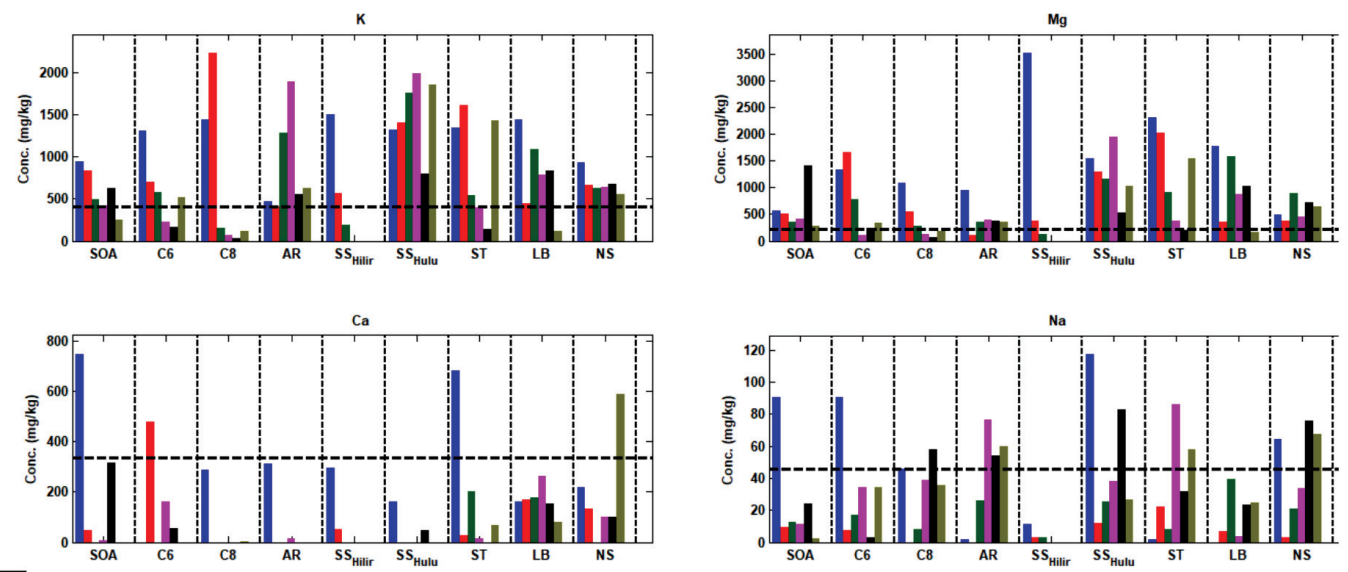

At the salt lick

$100 \mathrm{~m}$

$200 \mathrm{~m}$

$300 \mathrm{~m}$

$400 \mathrm{~m}$

$500 \mathrm{~m}$

Figure 6: The mineral concentrations in soils according to sites and distances (at an interval of $100 \mathrm{~m}$ )

\section{Conclusion}

The mineral compositions in the nine salt licks of Sarawak varied considerably. Profound abundance of $\mathrm{Na}$ was confirmed at sites spotted with sodium seeking species. The mineral concentrations were found to decline with increasing horizontal distance; at $500 \mathrm{~m}$, the mineral concentrations in most salt licks were close to or well below the level present in the control. The findings of this study can be used to suggest a suitable buffer distance for wildlife conservation and sustainable management of salt licks in Sarawak.

\section{Acknowledgements}

The authors thank the Dayak Chair, Institute of Borneo Studies (F07/ DRC/1456/2016) and Ta Ann Berhad (FL/F07/ ERTS/2017) for funding this project.

\section{References}

Best, E. C., Joseph, J., \& Goldizen, A. W. (2013). Facultative geophagy at natural licks in an Australian marsupial. Journal of Mammalogy, 94(6),1237-1247.

Boggs, C. L. \& Lee, A. J. (2008). Mud puddling by butterflies is not a simple matter. Ecological Entomology, 16(1), 123-127.

Brightsmith, D. J. \& Aramburu, R. (2004). Avian geophagy and soil characteristics in Southeastern Peru. Biotropica, 36(4), 534-543.

Carrow, R. N. \& Duncan, R. R. (2011) Best management practices for saline and sodic turfgrass soil: assessment and reclamation. Boca Ratonm Florida: CRC Press.

Hadley, D. (2017). Why do butterflies gathered around puddles. Retrieved from https:// www.thoughtco.com/why-do-butterfliesgather-around-puddles-1968178.

Holdo, R. M., Dudley, J. P., \& McDowell, L. R. (2002). Geophagy in the African elephant in relation to availability of dietary sodium. Journal of Mammalogy, 83(3), 652-664.

Hon J., Shibata S. \& Samejima H. (2020) Species composition and use of natural 
salt licks by wildlife inside a production forest environment in central Sarawak. In: Ishikawa N. \& Soda R. (Eds) Anthropogenic Tropical Forests. Singapore: Springer.

Hon, J. \& Shibata, S. (2013). Temporal partitioning by animals visiting salt licks. International Journal of Environment Science and Development, 4(1), 44-48.

Jordan, C. F. (1985). Nutrient cycling in tropical forest ecosystems. Chichester, New York: John Wiley \& Sons Canada, Limited.

Kamini, R. S. (2014). Set protection buffer around salt licks, urges WWF-Malaysia. The Rakya Post. Retrieved from http:// www.therakyatpost.com/life/2014/05/02/ set-protection-buffer-around-salt-licksurges-wwf-malaysia/.

Klaus, G., Kalus-Hugi, C., \& Schmid, B. (1998). Geophagy by large mammals at natural licks in the rain forest of the Dzanga National Park, Central African Republic. Journal of Tropical Ecology, 14, 829-839.

Lameed, G. A. \& Adetola, J. (2012). Speciesdiversity utilization of salt lick sites at Borgu sector of Kainji lake national park. Biodiversity Enrichment in a Diverse, 3562

Maiwald, M. \& Jayasilan, M. A. (2018) The advancement of camera trapping technique in understanding wildlife ecology in Sarawak. Malaysian Applied Biology, 47, $1-12$.

Matsubayashi, H. \& Lagan, P. (2014). Natural salt licks and mammals in Deramakot: Their importance and why they should be conserved. Sabah Forestry Department.

Matsubayashi, H., Lagan, P., Majalan, N., Tangah, J., Sukor, J. R. A., \& Kitayama, K. (2007). Importance of natural licks for the mammals in Bornean inland tropical rain forests. Ecological Research, 22, 742-748.

Milde, H., Weber, W. M., Salzet, M., \& Clauss, W. (2001). Regulation of $\mathrm{Na}^{+}$transport across leech skin by peptide hormones and neurotransmitters. Journal of Experimental Biology, 204, 1509-1517.

Mills, A. \& Milewski, A. (2007). Geophagy and nutrient supplementation in the Ngorongoro Conservation Area, Tanzania with particular reference to selenium, cobalt and molybdenum. Journal of Zoology, 271, 110-118.

Moe, S. R. (1993). Mineral content and wildlife use of salt licks in southwestern Nepal. Canadian Journal of Zoology, 71, 933-936.

Molina, E., Leon, T. E., \& Armenteras, D. (2014). Characteristics of natural salt licks located in the Colombian Amazon foothills. Environmental Geochemistry and Health, 36(1), 117-129.

Nderi, O. M., Musalia, L. M., \& Ombaka, O. (2015). Determination of essential minerals and toxic elements composition of the natural licks consumed by livestock in Tharaka-Nithi County, Kenya. IOSR Journal of Agriculture and Veterinary Science, 8(1), 45-53.

Neilsent, G. H. \& Edwards, T. (1982). Relationships between $\mathrm{Ca}, \mathrm{Mg}$ and $\mathrm{K}$ in soil, leaf and fruits of Okanagan apple orchards. Canadian Journal of Soil Science, 62, 365-374.

Panichev, A. M., Popov, V. K., Chekryzhov, I. Y., Serodkin, L. V., Sergievich, A. A., \& Golokhvast, K. S. (2017). Geological nature of mineral licks and the reasons for geophagy among animals. Biogeoscience, 14, 2767-2779.

Poole, K. G., Bachmann, K. D., \& Teske, I. E. (2010). Mineral lick use by GPS radiocollared mountain goats in South Eastern British Columbia. Western North American Naturalist, 70(2), 208-217.

Powell L. L., Powell, T., Powell, G., \& Brightsmith, D. (2009). Parrots take it with a grain of salt: available sodium content may drive collpa (clay lick) selection in Southeastern Peru. Biotropica, 41(3), 279282. 
Ramachandran, K. K., Malagopalan, M., \& Vijayakumaran, N. P. (1995). Use pattern and characterisation of the natural salt licks in Chinnar Wildlife Sanctuary. KFRI research Report 94, Kerala Forest Research Institute Peechi.

Stephenson, J. D., Mills, A., Eksteen, J. J., Milewski, A. V., \& Myburgh, J.G. (2011). Geochemistry of mineral licks at Loskop Dam Nature Reserve, Mpumalanga, South Africa. Environmental Geochemistry and Health, 33(1), 49-53.

Uddin, H. A. B. M., Khalid, R. S., Alaama, M., Abdualkader, A. M., Kasmuri, M. \& Abbas,
S.A. (2016). Comparative study of three digestion methods for elemental analysis in traditional medicine products using atomic absorption spectrometry. Journal of Analytical Science and Technology, 7(6), 1-7.

Vitousek, P. M. \& Sandford. R. L. (1986). Nutrient cycling in moist tropical forest. Annual Review of Ecology, Evolution and Systematics, 17, 137-167.

Weber, W. M., Dannenmaier, D., \& Clauss, W. (1993). Ion transport across leech integument. Journal of Comparative Physiology B, 163(2), 153-159. 